\title{
On the Application of $\mathrm{L} / \mathrm{C}$ in International Trade Payment
}

\author{
Guang SHAO \\ Henan Economy and Trade Vocational College \\ Zhengzhou, China
}

\begin{abstract}
The payment of the international sale of goods is an important content. For now, in China's foreign trade business, payment methods commonly used includes remittance, collection, as well as other ways of combining a variety of payment methods, which is widely used; it has more advantages and better Bank credit protection. This paper will pay letter of credit in international trade elaborate application for peer reference.
\end{abstract}

\section{Keywords- Trade; Pay; Credit}

\section{INTRODUCTION}

Letter of credit, a bank credit-based trade settlement tool is a bank (issuing bank) according to the importer (applicant) requirements and instructions, or on their own initiative for the exporter (beneficiary) to open out with a certain amount within the prescribed time limit. It is with the provision of a written document himself or authorizes another bank to the exporter or his designee payment commitments.

Because payments under L/C line with the entire purchase price is based on the shipping documents to obtain credit for the conditions specified in a way to avoid the risk of prepayment, easing the inlet and outlet is not in mutual payment and delivery issues trust. However, with the rapid development and the changing international trade settlement, settlement risks of credit instruments are exposed. Moreover, the bank receipt of payment and the buyer is no relation to the two links in $\mathrm{L} / \mathrm{C}$ transaction, resulting in an opportunity to criminals. It has a relationship to statistics, the world suffers each year due to credit card fraud and money that cannot be recovered, $2 \%$ to about $5 \%$ of the total amount of up to more than 200 billion dollars. Our country is the world's largest trading nation, every year because of credit to businesses, bank fraud caused billions of dollars in losses, even though the letter of credit in international trade has become an important method of payment, but buyers and sellers of all kinds of risks remain.

\section{THE BASIC CHARACTERISTICS OF TWO CREDITS}

Credit is the current method of payment in international trade that is the most common and effective settlement tool. It differs from the remittance (bank accepts customers entrust their funds remitted through banks or bank transfer for payment to the payee's business) and collection (exporter issued bill or bills to get to the mouth to banks. It is commissioned by its settlement bank on behalf of the importer to import receivables), and it is written with a certain amount of the Bank in accordance with the request of the importer to the exporter opened and documents within a certain period of commitment with the provisions of payment file. Letters of credit used in international trade settlement to the documentary credit based. The so-called documentary credit refers to the issuing bank under the applicant's request and in accordance with the instructions to create the conditions to meet $\mathrm{L} / \mathrm{C}$ requirements, a convention with the documents required for payment to a third party. It is based on the bank's credit-based payment. Credit has the following three characteristics:

\section{A. The Issuing Bank Bears Primary Responsibility for Payment}

Credit is the issuing bank promises to pay with their credit guarantee made. With the letter of credit, the issuing bank shall have the responsibility for the importer to bear down payment. The exporters obtain loans directly to the issuing bank, which the bank bears primary responsibility for payment, the seller is the first payer, unlike general security service in the bank bears only secondary responsibility (ie, on behalf of the bank before the payment in the case of nonpayment by the guarantor). Therefore, the height of the issuing bank must be aware of their responsibilities and risks.

\section{B. Credit is independent of the trade contraction of the transaction documents}

Open a letter of credit is based on the trade contract, but after opening the letter of credit will become independent of trade contracts and other contracts of another contract, which is bound by trade contracts and other contracts. International Chamber of Commerce Publication No. 500 of "Uniform Customs and Practice for Documentary Credits" (the UCP500) clearly states. "the issuing bank and the other banks involved in $\mathrm{L} / \mathrm{C}$ business undertaken are in accordance with the letter of credit payment, acceptance or negotiation or perform credit liability of any obligation under license. They are not subject to the applicant because of his relationship with the issuing bank or the beneficiary between the claims or defenses raised constraints; beneficiary in any case, which shall not use banks or between the applicant openers and the contractual relationship that exists between.

\section{Credit Deals with Documents rather than Goods}

The implementation of the principle of a credit voucher is for payment, rather than deals with the actual handling of the documents only trade in goods involved in the contract, so 
$\mathrm{L} / \mathrm{C}$ is actually a transaction document, the issuing bank for payment is based on the surface in line with the terms of the letter of credit documents. Therefore, the exporter (beneficiary) is to obtain money on the premise that the document that is consistent, that exporters must apply exactly as stated in $\mathrm{L} / \mathrm{C}$ documents, in order to obtain credit payments promptly. As can be seen, the importer is to receive the goods and guarantee authenticity that could not be confirmed in the letter of credit.

\section{THE SPECIFIC ROLE OF CREDIT IN INTERNATIONAL TRADE}

As a major international trade and means of payment, $\mathrm{L} / \mathrm{C}$ can be considered to carry out electronic business. There are many advantages of electronic credit. That is easy, safe, fast and accurate. Domestic trade buyers and sellers can be very quick and easy to understand each other's capital, capacity and

Credit situation, but in terms of international trade, it becomes more difficult, in this case, L/C delivery has become an important method of payment.

\section{A. The Important Role for Importer}

Export credit terms can be controlled shipment delivery, we should make sure to get in line with the trade contract documents, so as to ensure that the resulting future goods, they can comply with the contract on the biggest trade limits. Avoid large backlog of capital. Good sales of imported goods market, good credit, when issuing the importer may pay less or be exempted from the deposit, such as the issuing bank payments, redeem after the documents are paid before arrival, in that case, you can reduce the backlog of a lot of money.

\section{B. The important role for exporters}

There is the need to open a letter of credit in foreign trade, with the foreign exchange regulatory agency approval, so exporters can avoid some of L/C risk. As long as the shipper will comply with the terms of the letter of credit, it handed the exporter's bank dealings with it, so you can get the money, and you can accelerate capital turnover rate. To avoid the risk of money of the cargo, if the issuing bank is not able to pay it, but still holds the goods receipt, you can reduce some of the losses.

\section{The Important Role for Issuing Bank}

Issuing bank is to open letters of credit on behalf of Importers and Suppliers lent L/C instead of money, so that it does not have to occupy their own money, they can also get income issuing procedures, which can increase their sources of income. Issuing bank-lending credit is not unconditional, when issuing the Austrian ball has importer certain amount of margin, the margin can also be added as the market. At the same time, by conducting the issuing business, you can expand the bank's reputation in the international expansion of business areas. Role exporter banks are by notification, business negotiation, and so can get a certain number of settlement fees. In accordance with the principle of documents in line, after receiving the documents, but also to the issuing bank or its designated bank to obtain advance payment of the purchase price, which is to recover their money, the risk is relatively small point.

\section{THE CREDIT BUSINESS APPLICATIONS OF PAYMENT IN INTERNATIONAL TRADE}

Electronic credit business practice has flourished in the world of international trade settlement, currently the subject of electronic credit business is in the international arena, and there are two categories, namely, various commercial banks and some e-commerce companies. Various commercial banking system dominated by the general procedure of electronic credit business of such business is similar to the traditional use of L/C program, the main difference is that the whole process electronically. Other words, business negotiations are between buyers and sellers, orders, sales contracts signed, etc., which is generally the first EDI system through the network when the network will be settled by the importer to submit applications to electronic issuing bank. The issuing bank customers, according to the approved line of credit, according to the contents of the application, it is to the exporter (ie the beneficiary) open a letter of credit, and through the bank's internal operating system and the external network system. As for the system interface, the letter is sent to the location of the branch or agency exporters (ie advising bank). Advising bank check seal is correct; it will be forwarded to the exporters of electronic credit e-mail. Exporters with EDI systems can automatically review L/C, then automatically generated by the EDI system and the full set of documents sent to the transportation, insurance, customs and commodity inspection authorities. Other relevant departments are through the communication network and require these agencies, according to the contents of the letter of credit conditions and the actual cargo issued electronic documents such as invoices, bills of lading, insurance and so on. Export shipment in accordance with the provisions of the letter of credit in the future; we should get ready for all types of electronic documents, electronic bill out, negotiating bank for payment through a communications network. Negotiating bank EDI system is to examine the documents in accordance with the terms of $\mathrm{L} / \mathrm{C}$ that will correct the advance payment to the exporter, the electronic money order, shipping documents forwarded to the paying bank claims the issuing bank or it's designated by email. After issuing bank check and correct documents, payment is to the negotiating bank. Issuing notice import

People pay redeem, after the importer payment, issuing various types of electronic documents about to be forwarded to the importer, the importer of electronic documents and then forwarded through the network carriers in exchange for goods.

In China, China Merchants Bank online credit business is in a leading position in the domestic financial sector, its online credit only for the e-commerce market of member companies, providing a unified interface to connect with China Merchants Bank. In the e-commerce market turnover of contract, the buyer can immediately apply for the issuing by the CMB application that complies with the requirements of issuing immediate issuing by China Merchants Bank, the 
buyer and seller in the same time to get out of credit information through the corporate banking system, thereby initiating contract execution. Documents are submitted to the bank counter and still perform the audit. Leading ecommerce Company, e-business e-commerce Company credit-driven electronic credit business are influenced by three major e-commerce companies launched the system.

New York City, the company's e-commerce system Trade card are summarized its operational processes including transaction. Together, cargo transport, payment is with several stages. In addition to providing electronic market Trade card brokered contract, its payment mechanism is to examine the documents to ensure that the integration of Coface payment mechanism. Thomas Cook exchanges transfer mechanism, and it can build innovative financial supply chain management, integration negotiations, contracting, payment and shipping information management operations, which can significantly reduce trade File cost. Meanwhile, Trade card system will use electronic documents as buyers and sellers trade compliance delivery and payment of checks ginseng. Test is to avoid possible problems using its electronic trade documents on trading entity faces. London is as the main place of business e-commerce company development management that is an open, neutral, highly secure, legitimate Internet as support to the core information platform architecture-based electronic network, is committed to the elimination of the paper trade. After the signing of the agreement to become a member of the user, it is via the Internet to exchange documents, verification of data, to complete the trade process, after registration, to allow the transfer of ownership of the goods online. Bolero offers electronic credit payment starting in the core telecommunications carrier platform through an electronic bill of lading issued by the request of the consignor. Bolero has the rights registration system with all the information under a letter of credit (including electronic bills of lading, electronic insurance single, electronic inspection certificate, etc.). it is bundled together (hereinafter referred to as bundling of lading), and it is to determine the bill of lading holder according to the instructions. The circulation of information is bundled with the bill of lading by the current bundle tied to the bill of lading issued to the holder of the right to appoint another registration system bill of lading holder to carry out instructions. It is the consignor designated bank when the bill of lading holder of the bank should be completed under L/C advance payment liability; then specify the buyer for the bank bill of lading holder, the buyer should complete the payment redeem responsibility. When the final consignee becomes tied lading holder, he can be bundled with the bill of lading by electroporation. It is the means to return the child to the carrier or other person-designated carrier and request delivery. China National Golden Customs backbone, namely China International Electronic Commerce Network in 2005 also introduced credit BOLERO electronic notification system to provide more rapid and effective way for our exporters receive notification letter from the financial institution.

\section{CONCLUSIONS}

Canadian e-commerce software company developed the system will credit CCE Web system functionality and credit card is combined with integrated payment based on trade, trade flow and document management of the Internet and many other features, which can be global trade. The core of the system is the "Documents Clearing Center", which functions like Finance Bank, the various types of documents trade, transport, insurance, financing and other centralized processing and delivery. Payment under the letter of credit by the documents clearing centers, treatment modalities and bank letter of credit transaction, the center will examine the documents submitted by the beneficiary of the surface consistency, and after the end of the beneficiary to pay the entire transaction process. CCE Web system provides a secure electronic trading platform, but CCE Web system does not provide a right to registration centers to achieve property transfer between buyers and sellers.

Letter of credit practice is the typical trade guarantees net. The website promotion and marketing by United Front Work Department of the CPC Central Huaxing Economic Advisory Service Centre are responsible for the site. The China Construction Bank is in charge of fund management clients, weeping Network Technology Co., Ltd. Beijing that is responsible for the technical maintenance of its online credit-trading program under the following. The buyers are based on trade contracts to fill in the online "credit guarantee", the seller online confirmation letters of guarantee, buyers and sellers were submitted by $10 \%$ and $5 \%$ of the performance bond to guarantee companies; the security company after receiving a margin call seller stocking. The sellers after stocking in online enter "the seller of goods has been ready for notification"; the security companies notify the buyer to make up the money. It can notice to the seller after delivery guarantee company to collect the full payment; the seller shipped online, enter "seller shipping notice" and negotiable deposit guarantee; examination of the documents will guarantee documents submitted buyer, the buyer with the documents to receive goods from the carrier. This is a similar to the "pass-through credit. The Card "business not only changed its way of doing business in the form of letters of credit, but also completely changed the intrinsic nature of $\mathrm{L} / \mathrm{C}$.

\section{References}

[1] Sub Lin. On L/C application payment in international trade [J] Science and Technology Information, 2012,02: $233+235$

[2] Wang Qi. L/C application payment in international trade [J] modern economic information, 2012,01: 86.

[3] Xue Yuhua. Credit risk and aversion [J] in international trade payments in the Chinese commerce, 2013,35: $116+118$.

[4] Chen Yuan, Li Chen. Electronic letter of credit in international trade settlement application [J] Commercial Times, 2006,10: 70-72.

[5] Lu Xiuhua, Guodeng Ming. Electronic credit application in international trade settlement of $[\mathrm{J}]$ Yangtze University (Social Sciences), 2008,03: 66-69.

[6] $\mathrm{Xu} \mathrm{Li}$, Guo Lixia. Credit application and risk management in international trade [J] Chinese city finance, 1998,08: 53-54. 